\title{
The Effectiveness of Investment Incentives in Certain Foreign Companies Operating in the Czech Republic
}

\section{Cedidlová Miroslava}

\begin{abstract}
Since opening its borders, the Czech Republic has tried to attract foreign investors in order to become more competitive. A system of investment incentives was created and has been adapted to meet changing conditions. As in many countries, there are positive and negative opinions on the existence of investment incentives. Many agencies are trying to determine whether they are effective or not. The aim of this article is to find out if the investment incentives provided in the Czech Republic have been effective not only for companies but for the government as a provider as well. To do so, it provides a case study of firms that received investment incentives, charting the firm's development and profitability.
\end{abstract}

Key words: foreign direct investment, investment incentives, competitiveness, public subvention, public support.

\section{INTRODUCTION}

Instrument of investment incentives have been around for over 100 years. In the 19th century they were used in the United States of America, in the 20th century governments around the world began to offer direct grants, tax breaks, training funds, free infrastructure and other inducements to attract corporate investments. Moreover the well-known multinational companies take use of them. Investment incentives represent very large sums of government spendings and foregone revenue.

Since March 2012, quantitative and qualitative studies were conducted under the project, "Efficiency of Investment Incentives in the Czech Republic", IGA/FaME/2012/014. The aim of this research is to find out whether the investment incentives are effective. The qualitative research is performed on 30 companies that were granted investment incentives in the Czech Republic from April 1998 to June 2011.

\section{POSITIVE AND NEGATIVE SIDES OF INVESTMENT INCENTIVES}

\subsection{Definition of investment incentives}

First of all, it is necessary to explain what investment incentives are. According to the Organization for Economic Co-operation and Development (OECD, 2003, p. 12) investment incentives are „measures designed to influence the size, location or industry of a foreign direct investment project by affecting its relative cost or by altering the risks attached to it through inducements that are not available to comparable domestic investors". On the other hand, the United Nations Conference on Trade and Development (UNCTAD, 1996, p. 11) defines investment incentives 
in general as "measurable advantages provided by government to particular companies or group of companies with a goal to force them to behave some way". Thomas (2007, p. 11) describes investment incentives as "a subsidy given to affect the location of investment. The goal may be to attract new investment or to retain an existing facility".

\subsection{Positive sides of investment incentives}

Generally there are three opinions on investment incentives that should be considered as beneficial. Their indisputable advantages are effective gains available from gains from taxes and benefits. Tiebout (1956) noticed the behavior of governments in terms of public goods and taxes. The key for this observation was the reaction of household on offered services and taxation. Households moved to the suburb according to their preferred mix. This reaction is similar with the behavior of foreign companies and assures effectiveness.

Later, Black and Hoyt (1989) concluded that competing for investment can be effective when it moves governments to provide public services at marginal cost, rather than average cost. To do so, firms and governments should know the relevant investment costs at all locations. However this model addressed efficiency issues arising from the use of incentives and not equity questions. This resulted in opinion that location incentives are invested where the social benefit of the investment exceeds the private benefit of the investment.

Bartik (1991) considered that in the market for investment, the jurisdictions with the greatest need as high unemployment will offer the largest location subsidies. However Fisher and Peters (1998) pointed out that in this field of investment incentives does not work as a theory that the redistribution of jobs from places of low unemployment to places of high unemployment. The advantage stays that they can offer more projects than poorer areas.

Krugman (1994) represents strategic trade theory which counsels policy-makers facing a specific set of circumstances as increasing returns to scale and imperfect competition. This was researched especially in the airliner filed but is not oriented toward achieving global efficiency. Nevertheless this theory contributed to universal justification for incentives. According to UNCTAD (1996) financial incentives reduce the initial costs of the investment and lower the risk of the FDI project.

Srholec (2004) claims that it depends on governments reasons and if their influence is adequate to its costs and are important for decision and what they constitute for their investors. The basic arguments for support of FDI are the positive externalities which FDI are bringing. On the other hand investment incentives are deforming the investment decision because they are crowding out net supported investments and help to realize investments which would be profitable or are supporting investments realized even without government involvement.

Dreyhaupt (2006) provided research that investment incentives can increase efficiency. Its contribution can be seen in positive externalities or spillovers, making the social rate of return on the investment higher than the private rate of return on investment. According to this research incentives will increase a country's welfare if the investment projects take place. However the problem is with the practical applicability of the model.

Ginevičius and Šimelyte (2011) explored exogenous determinants of FDI. Two different models of FDI promotion were analyzed. The first one, the Irish model, refers to market liberalization and welcoming environment for FDI. However, the second one is more conservative, because 
the Taiwan-Korean-Chinese (TKC) model has strict rules for foreign investment and pays attention to cultural heritage and natural resources. Central and Eastern European countries behave conservatively and post-communist outlook is alive, the TKC model is more suitable for introducing FDI promotional policies. Deng, Falvey and Blake (2012) researched abolishing differential tax system in China and its reaction to FDI and spillovers in the short term. The result was restraining the foreign presence which is vital for FDI productivity spillovers. It enhances effectiveness of investment incentives. It leads to increasing the output level of domestic enterprises and promotes national welfare. In the result it can lift up the average productivity of all existing enterprises and raises the possibility of productivity spillovers and the absorptive capacity of domestic enterprises.

\subsection{Negative sides of investment incentives}

There are critics arisen about the use of investment incentives. The first argument against them is that governments could cooperate with each other to reduce the use of incentives, but they find it difficult to do so because of their competition for investment. This wide opinion is called Prisoners' Dilemma which sees a conflict between the individual incentives of local governments and what is collectively best for governments as a whole. Guisinger (1985) was the first to analyze location subsidies as a Prisoners' Dilemma.

Thomas (2000) thinks that from a national point of view, state or local incentives are often irrational in the sense that the investment will be made somewhere in the country. Blomstrom, Kokko and Zejan (2000) are against incentives for three reasons; firstly because without investment incentives multinational corporations (MNc) might not enter the host economy; secondly, it is very difficult to make calculations about expected future benefits; and thirdly, foreign investors do not differ from the local investors.

Most of them use arguments because they force governments to provide undesirably low levels of public services. Charlton (2003) pointed out that government will not have sufficient funds for important programs which could contribute to economic development such as education or infrastructure. He also noticed that keeping taxes low attracts business investments and local officials may hold spendings below optimal levels. On the other hand, Lynch (2004) is pessimistic and deems that state and local tax cuts paid by reducing public services can promote economic development and employment growth. Thomas (2007, p. 10) concluded that "investment incentives are not a marginal or geographically-limited phenomenon. On every continent, multiple levels of governments use location subsidies to try to promote investments. While some countries run low-tax regimes with few, if any, incentives, they are the exception rather than the rule." At the same time Thomas (2007) warns that investment incentives negatively affect efficiency, equity and the environment.

There are theories about the localized factors. However, many scientists such as Morisset and Pirnia (2000) or Markusen (1998) conclude that the localized importance is ambiguous according to the world's merit. While one side considers the market as the creator of the economic environment and contends that the government should only regulate competitive surroundings, the other side, adopting the Keynesians model, claims that the government should be active in the market (Holman, 1999). 


\subsection{Efficiency and effectiveness of investment incentives}

Investment incentives are world wide offered. Efficiency (a ratio) concerns the maximum profit on the minimum investment, whereas effectiveness does not take the amount of investment into account but only the results.

To display the efficiency, Cheshire and Gordon (1998) found out that the results of competition among local governments can have combinations of effects which fit into the following 2 -x-2 matrix. Based on this model, Rodriguez-Pose and Glauco Arbix (2001) suggested an innovative model for understanding the impact of investment incentives. It is based on the effect of subsidized investment on local and global efficiency. This model was used in Brazilian auto industry.

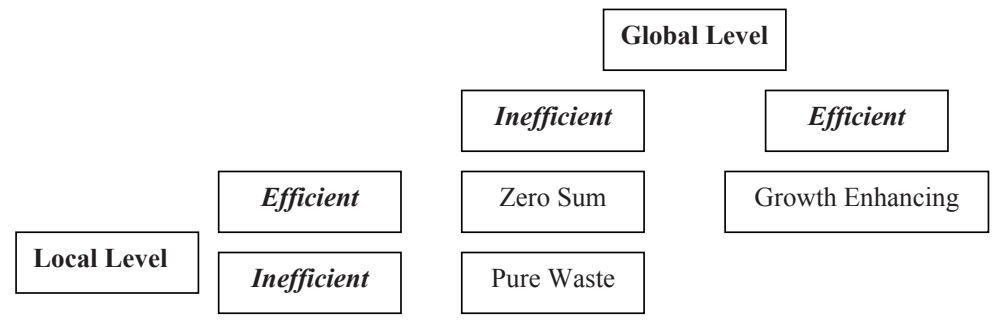

Fig. 1 - The Local vs. Global Efficiency Matrix. Source: Cheshire and Gordon (1998).

According to Fig. 1, if the competitive policy is locally and globally efficient then it enhances the growth. Increased economic welfare at the local level is not balanced by negative externalities in other parts of the country. However, if the improvements in efficiency at the local level cause losses somewhere in the country, they are considered zero-sum. The danger in competitive policies such as incentives could be in expensiveness of offset of local gains and it could also induce negative impacts in other parts of the country. Then the result could be pure waste of resources or in other words they are so-called fiscal wars.

The fourth quadrant stayed empty. It is so called the winners curse. This paradox can occur when a local jurisdiction overbids for an investment (they are locally inefficient) and it also happens to the location where the facility will operate most efficiently (they are globally efficient). Shifting an existing facility from a low-unemployment area to a high-unemployment area can be used as an example.

Christiansen, Oman and Charlton (2003) focused on the benefits of incentives against their costs and they claim that in some of the recipient states the efficiency gains outweighed the incentive costs. They analyzed the case in Brazil and they realized that the relocation of some automotive productions from Sao Paul to poorer areas of the country increased national efficiency.

\section{LEGAL PROCESS OF INVESTMENT INCENTIVES IN THE CZECH REPUBLIC}

After the Velvet Revolution in 1989, the government of the Czech Republic tried to attract foreign investors. All neighboring countries introduced systems of investment incentives, thereby 
increasing their competitiveness not only in a global context but against each other. From 1993 to 2011, the Czech Republic provided incentives worth 608 billion crowns which should have created 139,000 new jobs (Czechinvest, 2012).

Due to the transformation in the Czech Republic after the Velvet Revolution, it was necessary to jumpstart the economy. The government tried to do so through investment incentives. It was established The Investment and Business Development Agency - CzechInvest. More precisely, CzechInvest is a government agency whose task is to contribute to strengthening the Czech economy competitiveness through support for small and medium-sized enterprises, business infrastructure and innovation, and by attracting foreign investments in the areas of manufacturing, business support services and technology centres.

The government's task was to increase the attractiveness of the Czech economic environment for international investors. The acceptance alone of incentives marked a significant change in an economic policy previously focused on domestic companies. Incentives were nothing new because nearly every developed country in Europe offered them by the end of the 1990s.

Government decree No 298/98, passed in April 1998, established the conditions for the awarding of investment incentives. According to the decree, the investor was obliged to invest a minimum of 25 mil. USD. A subsequent government decree in December of that year reduced this amount to 10 mil. USD. Investment incentives were designed as follows:

- financial support for creation of new jobs,

- financial support for training and retraining new employees,

- corporate income tax relief for new companies,

- financial support for new production,

- financial support in case of expansion of production or modernization of production.

To receive investment incentives, the investor had to apply for them.

Government decrees defined the investment incentives and how they would be provided, but omitted investor obligations. As a result, it became a danger that foreign investors would apply for investment incentives, build a factory, use investment incentives and then move production to a cheaper country.

The first law which applied to investment incentives was No 72/2000. This Law about Investment Incentives took effect May 1, 2000. It was amended on February 24, 2001, and since then has provided investment incentives in a "statutory regime". This law established conditions and defined the process and solutions in the case that the conditions are not fulfilled. Its intent was to prevent the misuse of investment incentives, and it should assure the efficient distribution of public support in the form of investment incentives.

Law No 72/2000 has been amended six times, the latest amendment occurring in 2012. The revised law simplifies the application procedure for investment incentives (Czechinvest, 2012): As the law now stands, it provides the following:

- corporate income tax relief for new companies for ten years,

- regions A (regions which have an unemployment rate about 50\% higher than the average unemployment rate in the Czech Republic) can receive material support up to 50,000 CZK for the creation of new jobs, 
- material support for retraining employees up to $25 \%$ of the acknowledged costs,

- the minimum of the investment into the property is 50 mil. CZK in regions I (regions with the concentrated attention of the government), but a minimum of 25 mil. CZK into new machine equipment. In regions II (others regions) the state support is in amount of 100 mil. CZK with a minimum of 50 mil. CZK for new machine equipment.

\section{METHODOLOGY}

This part will explain how to calculate the effectiveness of investment incentives. At first it is necessary to focus on theoretical aspects that influence fiscal ( $\operatorname{tax})$ effectiveness, provided investment incentives are one of the possible kinds of public support offered by the government.

The government of a country provides investment incentives to an applicant (company). Since 1998 when the system of investment incentives was approved by the Czech government, foreign investors have been eligible for the following support: financial support for creating work places, subvention for costs related to retraining employees, income tax relief and subvention for supporting the development of an industrial estate. Each company that applies for investment incentives receives an official decision concerning their request.

The government provides a survey on maximum permissible state aid intensity in specific regions. The permissible state aid intensity is increased by $20 \%$ in the case of small enterprises and by $10 \%$ in the case of medium-sized enterprises.

In the calculation of the effectiveness of investment incentives from the government's point of view are considered the revenues (inputs) especially taxes, charges, insurance and the public health security. Taxes are considered as the yield of income tax resulting from the dependent activity of the firm's employees (15\%), the tax yield of the legal entity, and the income tax yield collected from the separated tax base special tax rate. Further, tax yields stem from the Vehicle Excise Duty, estate duty and various charges. Another source of revenues is insurance on social security; an employee pays $6.5 \%$ and employer deducts $25 \%$ from the employee's salary. The last revenue source is public health security, of which the employee pays $4.5 \%$ and employer $9 \%$.

Tax effectiveness is possible to express as revenues divided by expenditures in the following formula devised by Vybíhal (2002):

$E f=\frac{T n+T w+T v+T e+T o+I+H+S+T_{L E}}{W p+\operatorname{Re}+T r+D i+T c}(1)$

In the numerator are several variables considered as inputs to the state budget:

(Tn) yield of income tax of a natural person from the dependent activity,

(Tw) yield of income tax which is collected from the separated tax base special tax rate,

i. e. yield from the withholding tax,

(Tv) yield from the Vehicle Excise Duty,

(Te) yield from the estate duty,

(To) various charges,

(I) insurance on social security,

$(H)$ public health security, 
$(S)$ savings on the expenditure side of the state budget, for example savings on the amount of provision in the change of physical person on account of employment,

$\left(T_{L E}\right)$ tax yield of the legal entity.

Outputs in the process of pursuing fiscal (tax) effectiveness (Ef) is the real yield from taxes, alternatively other incomes from the state budget, as the determinative source of the income side of the public budgets, in particular considered as the denominator in the equation:

$\left(W_{p}\right)$ financial support on the created working place (in CZK),

$(R e)$ subvention for costs related to the retraining of employees, in CZK (other cost for retraining which are paid from the public budget),

(Tr) the amount of income tax relief (in CZK),

(Di) subvention for support the development of the industrial estate,

(Tc) administrative costs related to tax collecting.

Financial support for a newly created working place and subsidizing part of the cost for retraining are expenses from the point of view of the public budget. Its source lies in the collection of taxes and social insurance. The amount of tax relief does not belong to the expenditure part of the public budget as the investment incentives should have produced income for the public.

It should be noted that from the methodological point of view the model of the fiscal effectiveness was modified and there are not included yields of value added tax. In the studied company, the export exceeded the import, which influenced the excessive deduction, i. e. that the tax on input is higher than the amount of tax in output.

\section{RESULTS}

This research was done in 30 companies which received investment incentives in the Czech Republic. The observed duration was 5 years since receiving the investment incentives.

Much scientific research has been done on investment incentives, however there is still no clear answer, incorporating all factors, in determining their effectiveness. Agencies which are involved in providing investment incentives hire private auditors to confirm the contribution of incentives to the domestic economy or their effectiveness. The biased approach of these auditors invites criticism and draws their conclusions into question. However every project is unique and the costs which are implemented on them are high.

Based on economic debates related to investment incentives, sixty companies which received investment incentives or were promised investment incentives were contacted. The aim of this research is to find out whether the investment incentives are effective. The qualitative research is performed on 30 companies that were granted investment incentives in the Czech Republic from April 1998 to June 2011.

Twenty companies decided not to take investment incentives. This information is not revealed on the list of companies on the Czechinvest website. Ten companies chose not to cooperate in the research. In all companies, financial directors or the main accountant were contacted and were asked if they wish to join to project. After explaining the aim of the research they were asked to fill in the table sent to them via email. Tab. 1 provides more details about the researched com- 
panies and the amount of investment incentives they received. Eight companies manufacture transport vehicles; six are in engineering; and six in the electronic and electrotechnic industry.

Tab. 1 - Structure of researched companies. Source: author's own research

\begin{tabular}{|c|c|c|}
\hline $\begin{array}{c}\text { Number of Researched } \\
\text { companies }\end{array}$ & Applicant's Country of Origin & $\begin{array}{c}\text { Total Investment } \\
\text { (in mil. CZK) }\end{array}$ \\
\hline 8 & Germany & 8,356 \\
\hline 6 & Japan & 6,248 \\
\hline 5 & Sweden & 1,203 \\
\hline 4 & France & 1,7 \\
\hline 4 & Spain & 863 \\
\hline 3 & Great Britain & 678 \\
\hline Total: 30 & -- & 16,145 \\
\hline
\end{tabular}

Concerning the granted incentives from the 30 observed companies 29 took use of investment incentives in taxes; 20 in creating jobs; 13 companies used them for requalification of employees and 2 companies received land. None of the researched companies received investment incentives related to infrastructure.

According to the formula (1) in the previous part it was introduced the calculation of tax effectiveness expressed as revenues dividend by expenditures. The results are provided in the Tab. 2 .

Tab. 2 - Effectiveness of investment incentives. Source: author's own research

\begin{tabular}{|c|c|}
\hline Efficiency & Number of Companies \\
\hline $0.00-0.49$ & 2 \\
\hline $0.50-0.99$ & 2 \\
\hline $1.00-1.49$ & 3 \\
\hline $1.50-1.99$ & 4 \\
\hline $2.00-2.49$ & 7 \\
\hline $2.50-2.99$ & 4 \\
\hline $3.00-3.49$ & 2 \\
\hline $3.50-3.99$ & 2 \\
\hline $4.00-4.99$ & 1 \\
\hline $5.00-5.99$ & 1 \\
\hline $6.00-6.99$ & 2 \\
\hline Total & 30 \\
\hline
\end{tabular}

It is obvious that four companies out of the thirty have a lower effectiveness than 1 . It means that the financial support was not returned to the state budget and companies were ineffective. To the statistical expression the average value from the 30 companies is 2.586 and the median is 2.27 . It shows that observed companies are very effective. As remaining twenty-six companies were effective investments. Highlighted by company with the highest effectiveness of 6.71 , meaning it was able to provide returns 6.71 times to the state budget. 
A more detailed analysis will be focused on the most effective company and its contribution to the state budget.

Tab. 3 - Survey on Taxes of the company. Source: author's own research

\begin{tabular}{|c|c|c|c|c|c|c|}
\hline Input & 1999 & 2000 & 2001 & 2002 & 2003 & Total \\
\hline$T n$ & 27396436 & 35087794 & 16225835 & 13515083 & 13683155 & $\mathbf{1 0 5} \mathbf{9 0 8} \mathbf{3 0 3}$ \\
\hline$T w$ & 462979 & 12190 & 6160 & 5624 & 3394 & $\mathbf{4 9 0 6 3 7}$ \\
\hline$I$ & 9258428 & 13379664 & 14367282 & 15683552 & 16065316 & $\mathbf{6 8 7 5 4 2 4 2}$ \\
\hline$H$ & 3862454 & 5783343 & 67132115 & 6856392 & 7091948 & $\mathbf{3 0 3 0 7 3 4 8}$ \\
\hline$T v$ & 39275 & 45500 & 50225 & 55200 & 44475 & $\mathbf{2 3 4 6 7 5}$ \\
\hline$T e$ & 333255 & 333252 & 144162 & 206125 & 145186 & $\mathbf{1 1 6 1 9 8 0}$ \\
\hline$T o$ & 373400 & 924800 & 881000 & 1227600 & 1196400 & $\mathbf{4 6 0 3} \mathbf{2 0 0}$ \\
\hline$T_{L E}$ & 0 & 0 & 0 & 0 & 0 & $\mathbf{0}$ \\
\hline Total & 1208909 & 1315742 & 1081547 & 37549576 & 38229874 & $\mathbf{1 0 5 0 6 1 4 4 5}$ \\
\hline
\end{tabular}

(Tn) yield of income tax of a natural person from the dependent activity,

(Tw) yield of income tax which is collected from the separated tax base special tax rate, i. e. yield from the withholding tax,

(I) insurance on social security,

(H) public health security,

(Tv) yield from the Vehicle Excise Duty,

(Te) yield from the estate duty,

(To) various charges,

$\left(T_{L E}\right)$ tax yield of the legal entity.

Tab. 3 demonstrates that income tax of a natural person from the dependent activity is nearly 105 mil. CZK, the second biggest yield is insurance on social security and public health security (98 mil. CZK). The company's policy was to increase production and preserve key staff. During the twelve years studied, the company became dominant in its field. Retrained employees stayed with the company. However, the global economic crisis influenced the company significantly; profits decreased and sixty-five employees were made redundant. The question remains if the state support was effective enough for the government. According to the financial director, the company "was bleeding" but its internal policy was to keep going. In this case, it worked, and the company was able to ride out the storm.

This company received investment incentives in the following forms:

- 3 mil. CZK for retraining employees,

- 12 mil. CZK for creating 70 jobs.

The total state support was 15 million CZK.

The effectiveness can be calculated as 105,061,445/15,000,000 $=6.71$. It means that the provided investment incentives brought a return of 6.71 times the original investment. However this calculation was only for five years during the validity of investment incentives. To calculate just effectiveness is not enough. It is necessary to focus on the long-term financial indicators of the company. Fig. 2 displays the evolution of number of employees, sales and profit enterprise. 


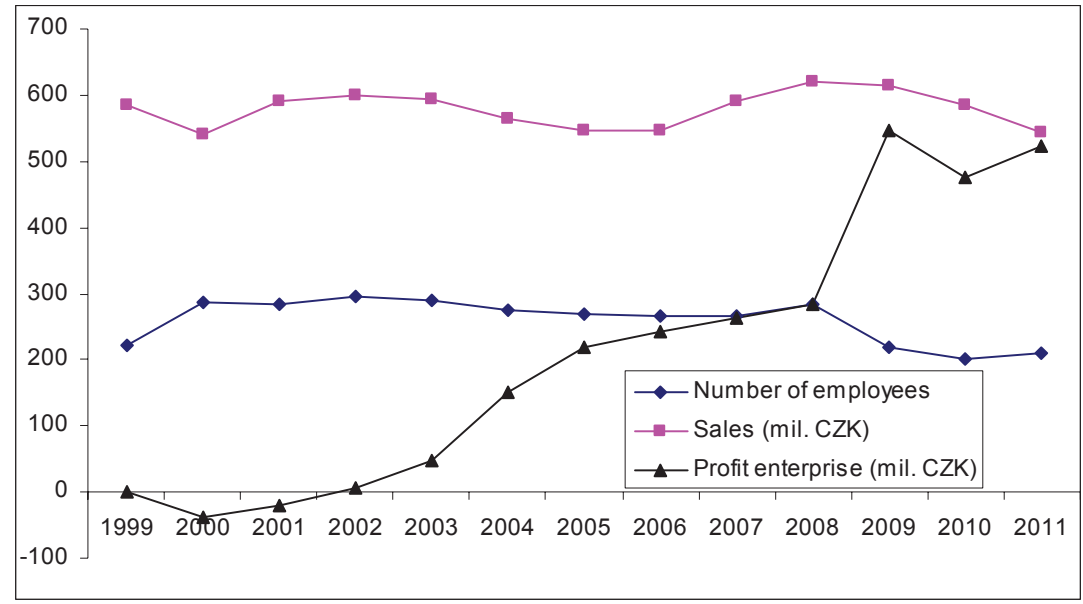

Fig. 2 - Evolution of the economic performance of the company. Source: author's own research

For the government and for regional development it is important to maintain production. The financial means are effective if they will be beneficial for both parties. It means that the government should receive a return in its investment and the company should be able to stay in the country and continue production.

\section{DISCUSSION}

As Thomas (2007) explains, nearly every government offers investment incentives. It evokes a question how it would be if instead of investment incentives governments lowered taxes as Altshuler, Gruberst and Newlon (1998) suggested. It was proved that some countries attracted foreign investors even without investment incentives. This act would help every company and the results would be controlled.

It could be agreed with Bartik (1991) that government offers investment incentives for places with the greatest need. In the case of the Czech Republic there are special rates for investment incentives in regions with the higher unemployment. The question stays if these regions will be helped by them for longer time period.

In this article it was showed that obtained investment incentives are mostly effective. Based on the formula and cooperation of companies it was possible to calculate inputs and outputs to the state budget. The company with the highest effectiveness influenced the surrounding and region because people moved to work there. Foreign investor brought new element to this area which can not be calculated.

In my opinion, if the government assures low taxes and maintains stability in the country, it will be favorable for investors without any investment incentives. Even if the research showed that investment incentives are effective, there is still no stable control over them. Governments should try protecting their economies and try becoming attractive by ensuring good economic conditions and avoiding grey economic areas such as tax evasion. In no case investment in- 
centives should pander to foreign investors. For investors the following factors are important: economic and political stability, production and work costs, qualified labor force, infrastructure, industry tradition, low costs, development of the country (Srholec, 2004). Economic and political stability should be a priority for the Czech government so as to assure foreign investment for Czech domestic companies.

The performance of foreign companies, which received investment incentives and are producing in the Czech Republic, is high. So as contributions in form of taxes, social and health insurance are extensive. However the attention should not be paid only for economic calculations in the form of outputs to the state budget but especially in creating new workforces, quality should be considered. Becoming an assembly line for multinational corporations is not optimal.

Nevertheless small companies should be more supported than big multinational corporations, especially agriculture and small farms so as to avoid a massive influx from neighboring countries. These entrepreneurships could enhance the Czech economy in the sense that these businesses can be observed by customers who, knowing the producer origin, will buy its products. Small entrepreneurs and if they are successful they can widen its production. However the economic climate and political stability is not so good or there are doubts about it.

\section{CONCLUSION}

This article was focused on effectiveness of investment incentives in foreign companies located in the Czech Republic. The aim of it was to find out if the provided investment incentives are effective and if the government receives any fiscal inputs in the form of taxes and other yields. The company which showed the highest effectiveness was studied over time. The analyzed results indicated that mainly it is effective to provide investment incentives. However, it would be worthwhile to create any methodology or instrument for analyzing its effectiveness directly from its provider - the Ministry of Industry and Development - and observing its contribution regularly.

\section{Acknowledgement:}

This paper is one of the research outputs of the project "Efficiency of Investment Incentives in the Czech Republic", registered at IGA/FaME/2012/014.

\section{References}

1. Altshuler, R., Grubert, H. \& Newlon, T. S. (1998). Has US Investment Abroad become more Sensitive to Tax Rates? Working Paper 6383. Cambridge (MA): National Bureau of Economic Research (NBER).

2. Bartik, T. J. (1991). Who Benefits from State and Local Economic Development Policies? Kalamazoo, Michigan: W.E. Upjohn Institute for Employment Research.

3. Black, D. \& Hoyt, W. (1989). Bidding for firms. The American Economic Review, 79(5), 12491256.

4. Blomstrom, M. \& Kokko, A. (2003). The economics of foreign direct investment incentives. Working Paper 168. Stockholm School of Economics. Retrieved January 16, 2012 from http://ideas. repec.org/p/hhs/eijswp/0168.html. 
5. Blomstrom, M., Kokko, A. \& Zejan, M. (2000). Firm and Host Country Strategies: Foreign Direct Investment. London: Macmillan.

6. Czechinvest (2012). Incentives which were granted from April 1998 to 15 August 2012. Retrieved September 15, 2012 from http://www.czechinvest.org/investicni-pobidky-nove.

7. Czechinvest (2012). Novela zákona o investičnich pobidkách. Retrieved from http://www. czechinvest.org/data/files/prehled-novela-investicnich-pobidek-3267-cz.pdf.

8. Czechinvest (2010). Finálni Zpráva vyhodnoceni dopadì investic cerpajicich pobidky a z̧hodnocení efektivity agentury CzechInvest. Retrieved from http://www.czechinvest.org/data/files/analyzadopadu-pobidek-na-cr-2050-cz.pdf.

9. Deng, Z., Falvey, R. \& Blake, A. (2012). Trading market access for technology? Tax incentives, foreign direct investment and productivity spillovers in China. Journal of Policy Modeling, 34(5), 675-690. http://dx.doi.org/10.1016/j.jpolmod.2012.01.003

10. Dreyhaupt, S. J. (2006). Locational Tournaments in the Context of the EU Competitive Environment. Wiesbaden: German University Verlag.

11. Ginevičius, R. \& Šimelyté, A. (2011). Government incentives directed towards foreign direct investment: a case of Central and Eastern Europe. Journal of Business Economics and Management, 12(3), 435-450. http://dx.doi.org/10.3846/16111699.2011.599415

12. Guisinger, Stephen E. (1985). A comparative study of country policies. In Stephen E. Guisinger and Associates, Investment Incentives and Performance Requirements. New York: Praeger.

13. Holman, R. (1999). Ekonomie. Praha: C. H. Beck.

14. Charlton, A. (2003). Incentive bidding for mobile investment: economic consequences and potential responses. No 203, OECD Development Centre Working Papers, OECD Publishing. http:// dx.doi.org/10.1787/864178271805

15. Cheshire, P. C. \& Gordon, R. I. (1998). Territorial Competition: Some Lessons for Policy. The Annals of Regional Science, 32(3), 126-146. http://dx.doi.org/10.1007/s001680050077

16. Christiansen, H., Oman, Ch. \& Charlton, A. (2003) Incentives-based competition for foreign direct investment: The case of Brazil. OECD Directorate for Financial, Fiscal, and Enterprise Affairs Working Papers on International Investment Number 2003/1.

17. Krugman, P. (1994). Complex Landscapes in Economic Geography. American Economic Review, 84(2), 412-16.

18. Lynch, R. G. (2004). Rethinking Growth Strategies: How State and Local Taxes and Services Affect Economic Development. Washington: Economic Policy Institute.

19. Markusen, J. R. (1998). Multinational Firms, Location and Trade. World economy, 21(6), 733756. http://dx.doi.org/10.1111/1467-9701.00161

20. Morisset, J. \& Pirnia, N. (2000). How Tax Policy and Incentives Affect Foreign Direct Investment, A Review. Working Paper 2509. Washinghton, D.C.: World Bank.

21. Organisation for Economic Co-operation and Development (OECD) (2003). Checklist for Foreign Direct Investment Incentive Policies. Paris: OECD.

22. Rodriguez-Pose, A. \& Arbix, G. (2001). Strategies of waste: Bidding wars in the Brazilian automotive sector. International Journal of Urban and Regional Research, 25(1), 134-154. http:// dx.doi.org/10.1111/1468-2427.00302 
23. Srholec, M. (2004). Prímé zabraniční investice v České republice. Teorie a praxe v mezinárodním srovnání. Praha: Linde,

24. Thomas, P. K. (2007). Investment incentives: Growing use, uncertain benefits, uneven controls. Geneva: Global Subsidies Initiative. Retrieved from http://www.iisd.org/gsi/sites/default/files/ gsi_investment_incentives.pdf

25. Thomas, P. K. (2000). Competing for Capital: Europe and North America in a Global Era. Washington: Georgetown University Press.

26. Tiebout, Ch. (1956). A pure theory of local expenditures. Journal of Political Economy, 64(5), 416-424. http://dx.doi.org/10.1086/257839

27. UNCTAD (1996). Incentives and Foreign Direct Investment. Current Studies, Series A, No. 30. New York and Geneve: United Nations.

28. Vybíhal, V. (2002). K problematice měření fiskální efektivnosti investičních pobídek. Sborník praci z. mezinárodni védecké conference Agrárni perspektivy XII., 1(1), 381-385.

\section{Contact information}

Ing. Miroslava Cedidlová

Tomas Bata University in Zlin, Faculty of Management and Economics

Mostni 5139, 76001 Zlin, Crech Republic

E-mail: cedidlova@rektorat.utb.cz. 